\title{
Effect of Kerosene and Gas Oil Products on Different Types of Concrete
}

\author{
Dr. Zena K. Abbas \\ Assistant Professor, University of Baghdad, College of Engineering, Iraq
}

\begin{abstract}
Kerosene and gas oil are very important products used as the source of energy all over the world. The use of concrete tanks are more appropriate compared with other materials for high durability, maintenance cost and fire resistance.The aim of the study is toadopt the mostsuitable concrete mixes from (plain concrete, reinforcement concrete with carbon and glass fiber, self compacted concrete and high strength concrete). The plain concrete showed the highest reduction for compressive and flexural strength, while the self compacted and high strength of concrete showed the better resistance to exposure of gas and kerosene oil products for 32, 62 and 152. The reduction in compressive and flexural strength is more for kerosene oil than gas oil for all types of concrete.
\end{abstract}

Keywords: Kerosene oil, gas oil, different types of concrete

\section{Introduction}

Petroleum products such as kerosene and gas oil as one of active sources of energy due to their operating and economic properties, there is a shortage of information about the behavior of different types of concrete under oil productsexposure and which of them is more suitable to use as oil products storage instead of the expensive steel storage. This research studied the effect of the oil products with different type of concrete.

The plain concrete, reinforced fiber concrete (RFC), high strength concrete (HSC) andself compacting concrete(SCC) are introduced by Zongjin Li 2011[1]:

Reinforced fiberconcrete composites are the cement composite with fiber, mostly short and discontinuous fibers, in order to overcome the two main deficiencies of cement based composites:

- The relatively low tensile strength

- Rather low energy consumption capacity or toughness.

High strength concrete is defined as concrete with a compressive strength higher than $50 \mathrm{MPa}$.

Self compacting concrete or self-consolidation concrete is a high fluidity concrete, easily placed and consolidated by its own gravity in a formwork, even with highly blocked reinforcements without vibration.

Fawzi and Al Ammer studied the effect of petroleum products (Kerosene and Diesel) on steel fiber reinforced concrete (FRC). The results of all tests of the specimens (plain and FRC with steel fiber) with different volume fraction $(0.5,0.75$ and $1 \%$ by volume of concrete) exposed to kerosene were better than specimens exposed to diesel [2].

Jasim and Jawad study the effect of oil (Kerosen, gas oil and crude oil) on the compressive and tensile strength for ordinary strength concrete and high performance concrete at $30,60,90$ and 120 day exposure after 28 days normal water curing. The test results showed that the loss in compressive strength and splitting tensile strength resulting from exposure to oil was relatively smaller for high performance concrete compared to normal strength concrete and the difference about $10 \%$ [3]. They also found that the reduction in the compressive strength increases with the decrease in viscosity of oil. The decrease in compressive strength was 25,19 and $15 \%$ for normal concrete and 12, 8 and $6 \%$ for high performance concrete exposed to kerosene, gas oil and crude respectively after 120 days of exposure.

Daib study the impact of engine oil on the compressive strength of concrete. The concrete cubes soaked in the used mineral oil for 6 months compared to those of normal concrete cubes in water. Five different concrete mixes were adopted toexamine the effect of mineral oil on low and high strength concrete. The aggressiveness of oil is very obviously for low and high strength concrete, the reductions in the compressive strengthup to (17\% and 11.8) \% respectively [4].

Al Swaidawi et al (2013) studied the effect of oil products (crude oil, motor oil, fuel oil and gas oil) on properties of self compacted concrete (SCC).They found that the compressive strength of SCC decreases as exposure period of oil products increase and the reduction at 60-80 days is between $(11.59-27.93) \%,(14.62-40.74) \%,(11.24-37.69) \%$ and (2.66-23.81)\% for SCC specimens exposure to crude oil, motor oil , fuel oil and gas oil respectively [5].

\section{Experimental Study}

\subsection{Materials}

Sulfate resistance Portland cement (Tasloja- Iraq)used which was conforms to the IQS 5/1984[6] and ASTM C1502010[7] for chemical analysis and physical properties listed in Table(1). 


\section{International Journal of Science and Research (IJSR) \\ ISSN (Online): 2319-7064 \\ Index Copernicus Value (2016): 79.57 | Impact Factor (2015): 6.391}

Table 1: Properties of sulfate resistance Portland cement

\begin{tabular}{|c|c|c|c|c|}
\hline & \multirow[t]{2}{*}{ Abbreviation } & \multirow{2}{*}{$\begin{array}{c}\text { Weight } \\
(\%)\end{array}$} & \multicolumn{2}{|c|}{ Specification } \\
\hline & & & $\begin{array}{c}\text { Iraqi } \\
\text { No. } 5 / 84\end{array}$ & $\begin{array}{c}\text { ASTM } \\
\text { C150-10 }\end{array}$ \\
\hline \multirow{8}{*}{$\begin{array}{c}\text { Chemical } \\
\text { analysis (\%) }\end{array}$} & $\mathrm{CaO}$ & 61.65 & - & - \\
\hline & $\mathrm{SiO}_{2}$ & 20.83 & - & - \\
\hline & $\mathrm{Al}_{2} \mathrm{O}_{3}$ & 3.75 & - & - \\
\hline & $\mathrm{Fe}_{2} \mathrm{O}_{3}$ & 4.24 & - & - \\
\hline & $\mathrm{SO}_{3}$ & 2.16 & $\leq 2.5 \%$ & $\begin{array}{c}\leq 2.3 \text { if } \\
\mathrm{C}_{3} \mathrm{~A} \leq 8 \%\end{array}$ \\
\hline & $\mathrm{MgO}$ & 3.25 & $\leq 5.0 \%$ & $\leq 6.0 \%$ \\
\hline & L.O.I. & 2.45 & $\leq 4.0 \%$ & $\leq 3.0 \%$ \\
\hline & I.R. & 0.65 & $\leq 1.5 \%$ & $\leq 0.75 \%$ \\
\hline \multirow{4}{*}{ Bogue's eq. } & $\mathrm{C}_{3} \mathrm{~S}$ & 55.25 & - & - \\
\hline & $\mathrm{C}_{2} \mathrm{~S}$ & 18.04 & - & - \\
\hline & $\mathrm{C}_{3} \mathrm{~A}$ & 2.76 & $\leq 3.5$ & $\leq 5.0$ \\
\hline & $\mathrm{C}_{4} \mathrm{AF}$ & 12.94 & - & - \\
\hline \multirow{5}{*}{$\begin{array}{l}\text { Physical } \\
\text { properties }\end{array}$} & $\begin{array}{c}\text { Blaine Fineness } \\
\left(\mathrm{m}^{2} / \mathrm{kg}\right)\end{array}$ & 285 & $230 \geq$ & $\geq 280$ \\
\hline & Soundness (\%) & 0.1 & $\leq 0.8$ & - \\
\hline & $\begin{array}{c}\text { Vicat's Setting } \\
\text { Initial (min) } \\
\text { Final (min) }\end{array}$ & $\begin{array}{l}0: 50 \\
6 \cdot 30\end{array}$ & $\begin{array}{l}\geq 45 \text { min } \\
<600 \text { min }\end{array}$ & $\begin{array}{l}\geq 45 \text { min } \\
<375 \mathrm{~min}\end{array}$ \\
\hline & Compressive & & & \\
\hline & $\begin{array}{c}\text { strength }(\mathrm{MPa}) \\
3 \text { days } \\
7 \text { days }\end{array}$ & $\begin{array}{l}19.5 \\
24.5\end{array}$ & $\begin{array}{l}\geq 15 \\
\geq 23\end{array}$ & $\begin{array}{l}\geq 8 \\
\geq 15\end{array}$ \\
\hline
\end{tabular}

-The natural sandwhich conformsto the Iraqi specification IQS 45/1984[8](zone 2) and ASTM C33-03[9] was used, with specific gravity $=2.65$ and fineness modulus $=3.0$. The sieve analysis, sulfate content and the physical propertieslistedin Table (2).

Table 2: Properties of sand

\begin{tabular}{|c|c|c|c|c|}
\hline \multicolumn{2}{|c|}{ Properties } & Results & $\begin{array}{c}\text { IQ No. 45/1984 } \\
\text { (Zone 2) }\end{array}$ & $\begin{array}{c}\text { ASTM } \\
\text { C33-03 }\end{array}$ \\
\hline \multirow{4}{*}{$\begin{array}{c}\text { Sieve } \\
\text { analysis- size } \\
(\mathrm{mm})\end{array}$} & 10 & $100 \%$ & 100 & 100 \\
\cline { 2 - 5 } & 4.75 & $94 \%$ & $90-100$ & $95-100$ \\
\cline { 2 - 5 } & 2.36 & $80 \%$ & $75-100$ & $80-100$ \\
\cline { 2 - 5 } & 1.18 & $60 \%$ & $55-90$ & $50-85$ \\
\cline { 2 - 5 } & 0.6 & $44 \%$ & $35-59$ & $25-60$ \\
\cline { 2 - 5 } & 0.3 & $18 \%$ & $8-30$ & $5-30$ \\
\cline { 2 - 5 } & 0.15 & $4 \%$ & $0-10$ & $0-10$ \\
\hline \multicolumn{2}{|c|}{ Sulfate (\%) } & 0.11 & $\leq 0.5$ & - \\
\hline \multicolumn{2}{|c|}{ Absorption (\%) } & 1.01 & - & - \\
\hline \multicolumn{2}{|c|}{ Moisture (\%) } & 2.5 & - & - \\
\hline \multicolumn{2}{|c|}{} & & & \\
\hline
\end{tabular}

- The natural crushed coarse aggregate (gravel) with maximum size of (20 and 14)mm was used. The aggregate satisfies the Iraqi specification IQS 45/1984[8] and ASTM C33-03[9],the sieve analysis, sulfate content and the physical propertieslisted in Table (3).

- The chemical admixture Glinume 51 was used which is complies in the ASTM C494-05 [10] types A and F.

- Silica fume was used in this study Elkem produced by (Efaco-Egypt).

Table 3: Properties of crushed gravel A\ Results

\begin{tabular}{|c|c|c|c|}
\hline \multicolumn{2}{|c|}{ Properties } & Max. Size=14 & Max. Size=20 \\
\hline \multirow{4}{*}{$\begin{array}{c}\text { Sieve } \\
\text { analysis- } \\
\text { mm }\end{array}$} & 37.5 & - & 100 \\
\cline { 2 - 4 } & 25 & - & 100 \\
\cline { 2 - 4 } & 20 & 100 & 96 \\
\cline { 2 - 4 } & 14 & 91 & - \\
\hline
\end{tabular}

\begin{tabular}{|c|c|c|}
\hline 10 & 70 & 45 \\
\hline 5 & 2 & 2.2 \\
\hline Sulfate $(\%)$ & 0.01 & 0 \\
\hline Specific gravity & 2.64 & 2.62 \\
\hline Absorption (\%) & 1 & 1.2 \\
\hline Moisture $(\%)$ & 1.6 & 1.2 \\
\hline Passing sieve size $75 \mu \mathrm{m}(\%)$ & 0.8 & 0.6 \\
\hline
\end{tabular}

B \ Requirements

\begin{tabular}{|c|c|c|c|c|c|}
\hline \multicolumn{2}{|c|}{ Properties } & \multirow{2}{*}{$\begin{array}{c}\text { IQ No. } \\
45 / 1984 \\
(5-20) \\
\end{array}$} & \multirow{2}{*}{$\begin{array}{c}\text { ASTM } \\
\text { C33-03 } \\
(4.75-19) \\
\end{array}$} & \multirow{2}{*}{$\begin{array}{l}\text { IQ No. } \\
45 / 1984 \\
(5-14)\end{array}$} & \multirow{2}{*}{$\begin{array}{c}\text { ASTM } \\
\text { C33-03 } \\
(4.75-12.5) \\
\end{array}$} \\
\hline & & & & & \\
\hline \multirow{7}{*}{$\begin{array}{c}\text { Sieve } \\
\text { analysis-mm }\end{array}$} & 37.5 & 100 & - & - & - \\
\hline & 25 & & 100 & - & - \\
\hline & 20 & $95-100$ & $90-100$ & 100 & 100 \\
\hline & 14 & - & - & $90-100$ & - \\
\hline & 12.5 & - & - & - & $90-100$ \\
\hline & 10 & $30-60$ & $20-55$ & $50-85$ & $40-70$ \\
\hline & 5 & $0-10$ & $0-10$ & $0-10$ & $0-15$ \\
\hline \multicolumn{2}{|c|}{ Sulfate (\%) } & $\leq 0.1$ & - & $\leq 0.1$ & - \\
\hline \multicolumn{2}{|c|}{ Passing size $75 \mu \mathrm{m}-\%$} & $\leq 3 \%$ & $\leq 1 \%$ & $\leq 3 \%$ & $\leq 1 \%$ \\
\hline
\end{tabular}

The chemical analysis and physical properties were listed in Table (4) and the pozzolanic strength activity index was 115 $\%$ (ASTM C1240-03[11] minimum requirements $=105 \%$ ).

All chemical analysis were made at research building center /Ministry of Constructions and Housing and the physical tests are carrying out in material Lab/Civil engineering Department /University of Baghdad

-Two types of fibers were used (carbon and glass fibers) produced by (Sika). The geometrical and physical characteristics are listed in Table (5). Finally the properties of oil products (kerosene and gas oil) were presented in Table (6), Oil analyses were made by the laboratory Al-Dura refinery

Table 4: Properties of silica fume

\begin{tabular}{|c|c|c|c|}
\hline \multicolumn{2}{|c|}{ Properties } & Results & ASTM \\
\hline \multirow{7}{*}{$\begin{array}{c}\text { Oxides } \\
\text { Composition } \\
(\%)\end{array}$} & $\mathrm{SiO}_{2}$ & 93.80 & $\geq 85 \%$ \\
\hline & $\mathrm{Al}_{2} \mathrm{O}_{3}$ & 2.23 & - \\
\hline & $\mathrm{Fe}_{2} \mathrm{O}_{3}$ & 1.32 & - \\
\hline & $\mathrm{CaO}$ & - & - \\
\hline & $\mathrm{MgO}$ & 2.02 & - \\
\hline & L.O.I & 0.7 & $\leq 6.0 \%$ \\
\hline & Moisture content & 0.82 & $\leq 3.0 \%$ \\
\hline \multicolumn{2}{|c|}{ Unit weight $\left(\mathrm{kg} / \mathrm{m}^{3}\right)$} & 2.45 & \\
\hline \multicolumn{2}{|c|}{ Specific Gravity } & 2.32 & \\
\hline \multicolumn{2}{|c|}{ Retained on sieve $45 \mu \mathrm{m}(\%)$} & 4.8 & $\leq 10 \%$ \\
\hline
\end{tabular}

Table 5: Technical properties of carbon and glass fibers

\begin{tabular}{|c|c|c|}
\hline Form & Carbon Fiber & Glass Fiber \\
\hline Density $\left(\mathrm{g} / \mathrm{cm}^{3}\right)$ & 1.9 & 2.7 \\
\hline Young modulus $(\mathrm{MPa})$ & $5500-7000$ & 8000 \\
\hline Tensile strength $(\mathrm{MPa})$ & 590 & 2500 \\
\hline Fiber length(mm) & 6 & 18 \\
\hline Fiber thickness (microns) & 7 & - \\
\hline Elongation at break (\%) & 1.4 & - \\
\hline
\end{tabular}

Table 6: Properties of oil products (kerosene and gas oil)

\begin{tabular}{|c|c|c|}
\hline & Kerosene oil & Gas oil \\
\hline Moisture content by volume (\%) & 0 & 0 \\
\hline Sulfur content by weight (\%) & 0.25 & 0.8 \\
\hline
\end{tabular}

\section{Volume 6 Issue 12, December 2017}


International Journal of Science and Research (IJSR)

ISSN (Online): 2319-7064

Index Copernicus Value (2016): 79.57 | Impact Factor (2015): 6.391

\begin{tabular}{|c|c|c|}
\hline Specific gravity $\left(\mathrm{gm} / \mathrm{cm}^{3}\right)$ at & & \\
$20^{\circ} \mathrm{C}$ & 0.782 & 0.821 \\
$25^{\circ} \mathrm{C}$ & 0.708 & 0.818 \\
$30^{\circ} \mathrm{C}$ & 0.702 & 0.812 \\
\hline Viscosity(centipoises) at & & \\
$20^{\circ} \mathrm{C}$ & 1.186 & 4.632 \\
$25^{\circ} \mathrm{C}$ & 1.089 & 3.780 \\
$30^{\circ} \mathrm{C}$ & 1.091 & 3.572 \\
\hline
\end{tabular}

\subsection{Mix Proportion and mixing method}

The concrete mix design is recommended according to the type of concrete as presented below and the mix proportion is presented in Table (7):

1) Plain concrete was designed according to ACI 211.1-91 [12] with slump rang (75-100) $\mathrm{mm}$ with specified compressive strength $35 \mathrm{MPa}$.The RFC was the same as plain concrete with fiber addition.

2) The SCC mix is designed according toEFNARK [13] with compressive strength about $50 \mathrm{MPa}$ at 28 days by trail mix the $\mathrm{W} / \mathrm{Cm}=0.35$.

3) The procedure of mixing follows the laboratory mixing procedure outlined by Emborg [14]. Table (8) presents slump flow, V-funnel and L-box results, and the specification according to EFNARK [13].

4) The HSC mix is designed according to ACI 211.4R08[15] to achieve characteristic compressive strength of $50 \mathrm{MPa}$ at 28 days with slump $100 \mathrm{~mm}$ and the $\mathrm{W} / \mathrm{Cm}=0.31$. Mixing process is performed according to ASTM C192-02[16].

Table 7: Mix proportions for concrete mixes

\begin{tabular}{|c|c|c|c|c|c|}
\hline Mix & $\begin{array}{c}\text { Sand } \\
\left(\mathrm{kg} / \mathrm{m}^{3}\right)\end{array}$ & $\begin{array}{c}\text { Gravel } \\
\left(\mathrm{kg} / \mathrm{m}^{3}\right)\end{array}$ & $\begin{array}{c}\text { Water } \\
\left(\mathrm{kg} / \mathrm{m}^{3}\right)\end{array}$ & $\begin{array}{c}\text { SP } \\
\left(1 / \mathrm{m}^{3}\right)\end{array}$ & $\begin{array}{c}\text { Slump } \\
(\mathrm{mm})\end{array}$ \\
\hline Plain concrete (MR) & 650 & 1000 & 205 & - & 85 \\
\hline $\begin{array}{c}\text { Reinforced concrete with } \\
\text { glass fiber (MG0.5) }\end{array}$ & 800 & 1000 & 155 & 4.7 & 80 \\
\hline $\begin{array}{c}\text { Reinforced concrete with } \\
\text { glass fiber (MG1.0) }\end{array}$ & 800 & 1000 & 155 & 5.0 & 78 \\
\hline $\begin{array}{c}\text { Reinforced concrete with } \\
\text { Carbone fiber (MC0.5) }\end{array}$ & 800 & 1000 & 155 & 4.7 & 82 \\
\hline $\begin{array}{c}\text { Reinforced concrete with } \\
\text { Carbone fiber (MC1.0) }\end{array}$ & 800 & 1000 & 155 & 5.0 & 80 \\
\hline $\begin{array}{c}\text { Self-compacted concrete } \\
\text { (SCC) }\end{array}$ & 750 & $800^{*}$ & 175 & 5.2 & - \\
\hline $\begin{array}{c}\text { High strength concrete } \\
\text { (HSC) }\end{array}$ & 750 & $800^{* *}$ & 155 & 4.3 & 75 \\
\hline
\end{tabular}

Cement content $=450\left(\mathrm{~kg} / \mathrm{m}^{3}\right), \mathrm{SF}=50 \mathrm{~kg} / \mathrm{m}^{3}$ for $\mathrm{SCC}$ and $\mathrm{HSC}$ MG0.5and MC0.5=0.5\% fiber addition for FRC

MG1.0 and MC1.0=1\% fiber addition for FRC

$*$ Maximum size $=14 \mathrm{~mm}, * *$ maximum size $=20 \mathrm{~mm}$

Table 8: Slump flow, V-funnel and L-box for SCC

\begin{tabular}{|c|c|c|c|c|c|}
\hline \multirow{2}{*}{ Test } & \multicolumn{2}{|c|}{ Slump flow } & \multicolumn{2}{|c|}{ V-funnel } & L-box \\
\cline { 2 - 6 } & $\begin{array}{c}\mathrm{SF} \\
(\mathrm{mm})\end{array}$ & $\begin{array}{c}\mathrm{T} 50 \mathrm{~cm} \\
(\mathrm{sec})\end{array}$ & $\begin{array}{c}\mathrm{Vf} \\
(\mathrm{sec})\end{array}$ & $\begin{array}{c}\mathrm{Vf}_{5 \min } \\
(\mathrm{sec})\end{array}$ & $\left(\mathrm{h}_{2} / \mathrm{h}_{1}\right)$ \\
\hline $\begin{array}{c}\text { Specification } \\
\text { (EFNARK) }\end{array}$ & $650-800$ & $2-5$ & $6-12$ & +3 & $0.8-1.0$ \\
\hline Results & 665 & 5 & 9 & 12 & 0.81 \\
\hline
\end{tabular}

\subsection{Curing of Concrete}

The specimens were cured in tap water at laboratory temperature up to the age of 28-days. After that they were dried in oven at $75^{\circ} \mathrm{C}$ until reaching almost a constant weight, and then immersed in oil products for 30, 60 and 90day. To provide a basis for comparison, refrence specimens for each type of concrete were cast and exposed to water for a respective time of test

\section{Experimental Test}

- -Slump test: The slump test of fresh concrete for (plain concrete, FRC and HSC) is according to ASTM C143/C143M [17]

- Slump flow, V-funnel and L-box for SCC:The slump flow and $\mathrm{V}$-funnel test is used to determine the filling ability (flowability) of the SCC in the absence of obstructions [13]. The L-box test assesses the flow of the concrete, and also the extent to which it is subject to blocking by reinforcement to assess filling and passing ability of SCC [13].

- -Compressive Strength: The compressive strength test was determined according to BS 1881: part 116: 1989[18]. The test was conducted at 28-days at water cutting tank and ages of 30,60 and 90 after 28-days of water curing and oil productsexposure.

- Flexural Strength: The $(100 \times 100 \times 400) \mathrm{mm}$ specimens were determined by applying two-point loading according to ASTM C78[19].

\section{Results}

The effects of kerosene and gas oil on the compressive and flexural strength of concrete were investigated. Different types ofconcrete mixes were prepared (plain, fiber reinforced with carbon and glass fiber, SCC and HSC) and soaked in oil for a curing period of 5 months after 28-days normal curing in water. Table (9) represents the compressive strength results for all types of concrete for normal curing in water and the exposure of oil.

The reductions in compressive strength are shown in Figure (1) for gas oil products. The plain concrete showed the higher reduction in compressive strength up to $(3.88,5.74$ and 11.82) at 32, 62 and 152 days of exposures respectively. While the SCC and HSC showed an enhancement in compressive strength and the lowest reduction up to (1.76, 4.45 and 6.33) for SCC and (2.76, 3.53 and 5.07) for HSC at 32,62 and 152 days of exposures respectively.

The exposure to kerosene oil is more effective as shown in Figure (2). The plain concrete also showed the higher reduction in compressive strength up to $(6.21,6.66$ and 13.9) at 32, 62 and 152 days of exposures respectively. The SCC and HSC also showed the lowest reduction up to (4.62, 5.73 and 7.22) for SCC and (4.49, 5.52 and 6.82) for HSC at 32, 62 and 152 days of exposures respectively.

The more effect of gas oil than kerosene is compatible with Jasim and Jawad [3]. This may be attributed to the lower viscosity of kerosene than gas oil [22].

The decrease in compressive strength for the plain and fiber reinforced concrete exposed to oil products may be due to the weakening in the boned strength between cement paste and aggregate and between concrete ingredients and fiber

\section{Volume 6 Issue 12, December 2017




\section{International Journal of Science and Research (IJSR) \\ ISSN (Online): 2319-7064}

Index Copernicus Value (2016): 79.57 | Impact Factor (2015): 6.391

with time of exposure and that is compatible with Fawzi and Al Ammer[2], Al Harby[20] and Rashed[21]results.

The flexural strength results are presented in Table (10). The behavior is compatible to compressive strength for plain concrete, SCC and HSC while the fiber reinforced concrete showed the highest flexural strength with lowest reduction as shown in Figure (3) and (4) for gas and kerosene oil productsrespectively. The percentage reduction for plain concrete equals to $(3.52,4.62$ and 8.46) for gas oil and (4.56, 5.84 and 9.64) for kerosene oil at 32, 62 and 152 days of exposures respectively.

Table 9: Compressive strength results for normal curing and oil products

\begin{tabular}{|c|c|c|c|c|c|c|c|c|}
\hline & Age -day & \multicolumn{7}{|c|}{ Compressive strength (MPa) } \\
\cline { 3 - 9 } & (exposure) & M & MG & MG & MC & MC & SCC & HSC \\
& & & 0.5 & 1.0 & 0.5 & 1.0 & & \\
\hline Water & 7 & 23.8 & 26.1 & 28.5 & 26.5 & 29.2 & 48.0 & 48.2 \\
\cline { 2 - 9 } & 28 & 35.2 & 36.5 & 38.9 & 37.8 & 39.7 & 54.5 & 57.3 \\
\cline { 2 - 9 } & 60 & 38.6 & 41.6 & 42.2 & 42.5 & 43.1 & 56.2 & 57.8 \\
\cline { 2 - 9 } & 90 & 43.5 & 47.1 & 49.8 & 47.5 & 50.2 & 62.8 & 65.1 \\
\cline { 2 - 9 } & 180 & 48.2 & 52.6 & 53.6 & 53.7 & 54.5 & 66.3 & 68.9 \\
\hline \multirow{4}{*}{ Gas } & $60(32)$ & 37.1 & 40.2 & 41.0 & 41.2 & 42.0 & 55.2 & 56.2 \\
\cline { 2 - 9 } & $90(62)$ & 41.0 & 45.1 & 47.9 & 46.1 & 48.5 & 60.0 & 62.8 \\
\cline { 2 - 9 } & $180(152)$ & 42.5 & 46.9 & 48.3 & 48.5 & 49.2 & 62.1 & 65.4 \\
\hline \multirow{3}{*}{ Ker. } & $60(32)$ & 36.2 & 39.2 & 40.2 & 40.0 & 41.1 & 53.6 & 55.2 \\
\cline { 2 - 8 } & $90(62)$ & 40.6 & 44.6 & 47.2 & 44.9 & 47.5 & 59.2 & 61.5 \\
\cline { 2 - 8 } & $180(152)$ & 41.5 & 46.2 & 48.0 & 47.5 & 49.0 & 61.5 & 64.2 \\
\hline
\end{tabular}

Table 10: Flexural strength results for normal curing and oil products

\begin{tabular}{|c|c|c|c|c|c|c|c|c|}
\hline & \multirow{2}{*}{$\begin{array}{l}\text { Age -day } \\
\text { (exposure) }\end{array}$} & \multicolumn{7}{|c|}{ Flexural strength $(\mathrm{MPa})$} \\
\hline & & M & $\begin{array}{c}\mathrm{MG} \\
0.5\end{array}$ & $\begin{array}{c}\text { MG } \\
1.0\end{array}$ & $\begin{array}{c}\mathrm{MC} \\
0.5\end{array}$ & $\begin{array}{c}\mathrm{MC} \\
1.0\end{array}$ & SCC & HSC \\
\hline & 7 & 3.65 & 8.82 & 10.54 & 9.25 & 10.82 & 4.55 & 4.65 \\
\hline & 28 & 4.92 & 10.22 & 11.14 & 11.25 & 12.05 & 5.15 & 5.25 \\
\hline & 60 & 5.25 & 11.82 & 12.82 & 12.05 & 13.25 & 5.52 & 5.65 \\
\hline & 90 & 5.65 & 12.10 & 13.52 & 12.82 & 14.05 & 5.92 & 6.15 \\
\hline & 180 & 5.80 & 13.5 & 15.11 & 13.75 & 15.82 & 6.35 & 6.55 \\
\hline \multirow{3}{*}{ ల్లి } & $60(32)$ & 5.06 & 11.53 & 12.53 & 11.83 & 13.05 & 5.38 & 5.51 \\
\hline & $90(62)$ & 5.38 & 11.78 & 13.18 & 12.53 & 13.77 & 5.74 & 5.98 \\
\hline & $180(152)$ & 5.31 & 12.98 & 14.57 & 13.25 & 15.30 & 6.11 & 6.32 \\
\hline \multirow{3}{*}{ 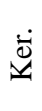 } & $60(32)$ & 5.01 & 11.52 & 12.52 & 11.81 & 13.00 & 5.37 & 5.34 \\
\hline & $90(62)$ & 5.32 & 11.77 & 13.16 & 12.50 & 13.74 & 5.74 & 5.96 \\
\hline & $180(152)$ & 5.24 & 13.02 & 14.60 & 13.23 & 13.26 & 6.10 & 6.11 \\
\hline
\end{tabular}

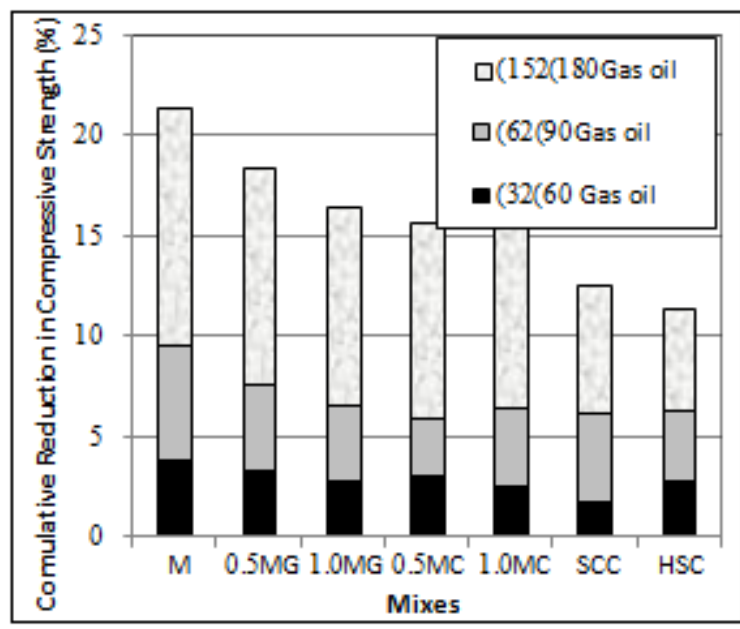

Figure 1: Copulative reduction in compressive strength for gasoil exposure compered to normal curing

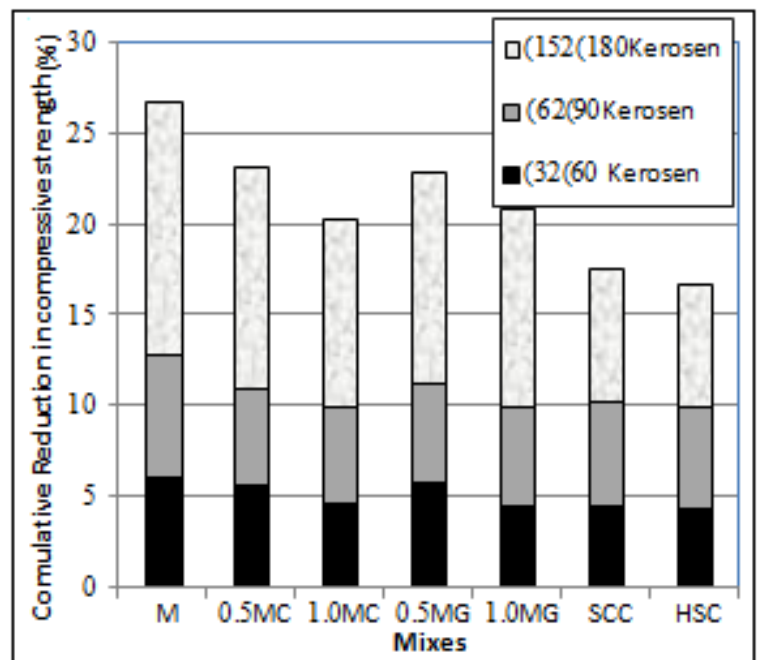

Figure 2: Copulative reduction in compressive strength for gas oil exposure compered to normal curing

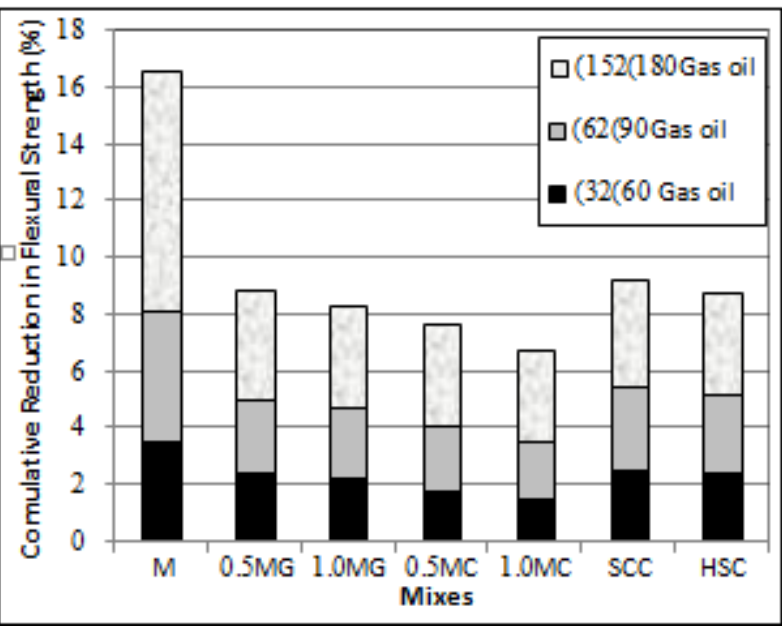

Figure 3: Copulative reduction in flexural strength for Kerosene exposure compered to normal curing

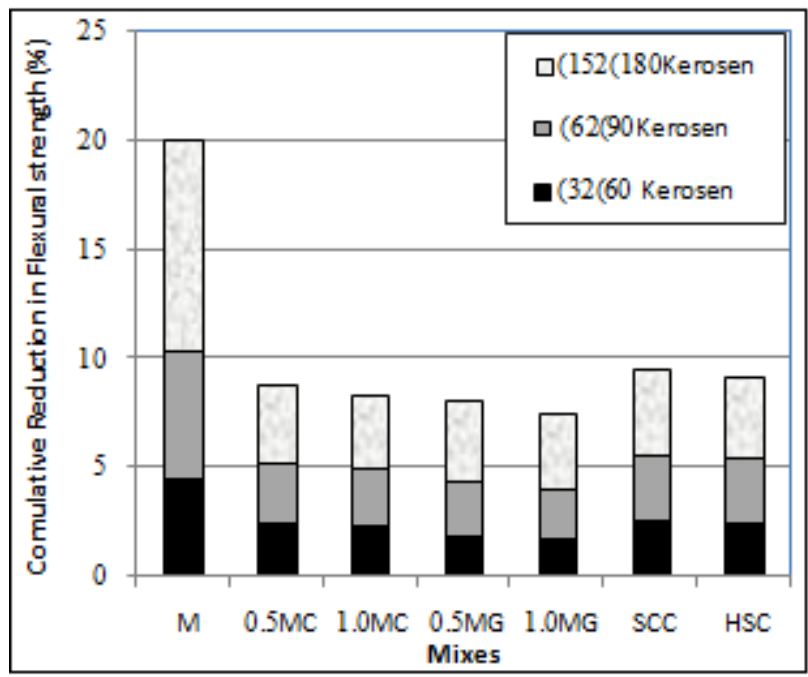

Figure 4: Copulative reduction in flexural strength for gas oil exposure compered to normal curing

\section{Conclusions}

1) The plain concrete showed the highest reduction in compressive and flexural strength up to (11.82 and 8.46)

\section{Volume 6 Issue 12, December 2017}


$\%$ respectively for gas oil and (13.9 and 9.64)\% for kerosene oil compered to normal water curing 152 days of exposure.

2) The reduction in compressive and flexural strength is more for kerosene oil than gas oil for all types of concrete.

3) The self compacted and high strength concrete showed the butter resistance to exposure

\section{References}

[1] ZongjinLi , "Advanced Concrete Technology" ,The book by by John Wiley \& Sons, 2011

[2] N. M. Fawzi and S. A. Abed AL-Ameer," Effect of Petroleum Products on Steel Fiber Reinforced Concrete", Journal of Engineering,Vol.19,No.1,2013

[3] A. T. Jasim and F. A. Jawad," EFFECT OF OIL ON STRENGTH OF NORMAL AND HIGH PERFORMANC CONCRETE, Al-Qadisiya Journal for Engineering Sciences, Vol. 3, No. 1, 2010.

[4] H. Diab," Compressive strength performance of lowand high-strength concrete soaked in mineral oil",Construction and Building Materials,Vol. 33, 2012.

[5] A. A. Al Swaidawi, S.A. Al-Mishhadani and W. Khalil " Properties of self compacting concrete exposed to oil products, MsC. Thesis, University of Technology,2013.

[6] IQS- 5,"Iraq standard specification for Portland cements", 1984.

[7] ASTM C150, "Standard Specification for Portland Cement", American Society for Testing and Materials, 2010.

[8] IQS- 45,"Aggregate from natural sources for concrete and building construction, 1984.

[9] ASTM C33," Standard Specifications for Concrete Aggregate", American Society for Testing and Materials, 2007.

[10]ASTM C 494/C 494M," Standard specification for chemical admixtures for concrete" ASTM International,1999.

[11]ASTM C1240, "Standard Specification for Silica Fume Used in Cementitious Mixtures". , American Society for Testing and Materials, 2003.

[12] ACI 211.1,"Standard Practice for Selecting Proportions for Normal, Heavyweight, and Mass Concrete", American Society for Testing and Materials, (Reapproved 2009).

[13] EFNARC, "Specification and Guidelines for Self-Compacting Concrete", www.efnarce.org , February 2002.

[14] M. Emborg"Mixing and Transport", BriteEuRam, Task 8.1, June 2000.

[15]ACI Committee 211.4R, "Guide for Selecting Proportions for High Strength Concrete with Portland Cement ", 2008.

[16] ASTM C192-02[15]

[17] ASTM C 143," Standard test method for slump of hydraulic-cement concrete", American Society for Testing and Materials, 2005.

[18]B.S.1881: part 116,"Methods for determination of compressive strength of concrete cubes", British Standard Institution, 1983.
[19]ASTM C78, "Standard Test Method for Flexural Strength of Concrete'. , American Society for Testing and Materials, 2005.

[20] M. J. Al Harby, "Effect of oil products on construction", Lab Union Center, Baghdad, 1998.

[21]L. Rashed, "Behavior of fiber reinforced concrete exposed to oil", M.Sc. Thesis, University of technology, Baghdad, 1998.

[22] S.T. Abdul-Hussain," Effect of oil products on compressive strength of reactive powder concrete", ALQadisiya Journal for Engineering Sciences, Vol. 6, No. 4, 2013.

\section{Author Profile}

Assistant professor Dr.Zena K. Abbas received her B.Sc. in civil engineering -University of Baghdad in 1997. She received her M.Sc. and Ph.D. degrees in material construction since from the University of Baghdad in 2004 and 2010 respectively. Since 1997, she is a faculty member in the Civil Engineering Department-University of Baghdad. 